\title{
Avaliação da eficácia de diferentes protocolos de preparo do Plasma Rico em Plaquetas para uso em Medicina Equina ${ }^{1}$
}

\author{
Cynthia P. Vendruscolo ${ }^{2}$, Armando de M. Carvalho ${ }^{2}$, Lívia F. Moraes ${ }^{3}$, Leandro Maia ${ }^{3}$, \\ Diana L. Queiroz ${ }^{2}$, Marcos J. Watanabe ${ }^{2}$, Ana Lúcia M. Yamada ${ }^{2}$ e Ana Liz G. Alves ${ }^{2 *}$
}

\begin{abstract}
Vendruscolo C.P., Carvalho A.M., Moraes L.F., Maia L., Queiroz D.L., Watanabe M.J., Yamada A.L.M. \& Alves A.L.G. 2012 [Evaluating the effectiveness of different protocols for preparation of platelet rich plasma for use in equine medicine.] Avaliação da eficácia de diferentes protocolos de preparo do Plasma Rico em Plaquetas para uso em Medicina Equina. Pesquisa Veterinária Brasileira 32(2):106-110. Departamento de Cirurgia e Anestesiologia Veterinária, Faculdade de Medicina Veterinária e Zootecnia, Universidade Estadual Paulista, Distrito de Rubião Júnior s/n, Botucatu, SP 18618-970, Brazil. Email: anaalves@fmvz.unesp.br

Platelet-rich plasma (PRP) is a prepared of the whole blood which contains several growth factors responsible for cellular proliferation and differentiation, angiogenesis, and for the increase of the extracellular matrix. Thus, the aim of this study was to test 10 different centrifugation protocols to obtain PRP from the whole blood of healthy equines. Ten samples of $27 \mathrm{~mL}$ of the whole blood of 5 healthy equines were used, which were centrifuged in accordance to the proposed protocols. The results showed that the protocols with less relative centrifugation force resulted in greater $(\mathrm{p}<0,05)$ platelets concentration. Also, platelets concentration was not influenced by varying the time of centrifugation. However, time did affect the number of leukocytes in some protocols. The best four protocols were analyzed by ELISA test to quantitate the amount of TGF- $\beta$, which revealed no difference ( $p>0.05$ ) between the protocols.
\end{abstract}

INDEX TERMS: Horse, platelet-rich plasma, centrifugation, whole blood.

RESUMO.- O Plasma Rico em Plaquetas (PRP) é um preparado do sangue total que contém diversos fatores de crescimento responsáveis pela proliferação e diferenciação celular, angiogênese, como também pelo aumento da produção da matriz extracelular. Nesse sentido, o objetivo do presente estudo foi testar 10 protocolos diferentes de centrifugação para obtenção de PRP a partir do sangue total de equinos hígidos. Para isso foram utilizadas 10 amostras de $27 \mathrm{~mL}$ de sangue total de cinco animais, as quais foram centrifugadas conforme cada protocolo proposto. Os resultados revelaram que os protocolos com menor força de centrifugação relativa resultaram em maior $(p<0,05)$ concentração de plaque-

\footnotetext{
${ }^{1}$ Recebido em 14 de março de 2011.

Aceito para publicação em 4 de outubro de 2011.

${ }^{2}$ Departamento de Cirurgia e Anestesiologia Veterinária, Faculdadede Medicina Veterinária e Zootecnia (FMVZ), Universidade Estadual Paulista (Unesp), Distrito Rubião Júnior s/n, Botucatu, SP 18618-970, Brasil. *Autor para correspondência: anaalves@fmvz.unesp.br

${ }^{3}$ Departamento de Clínica Veterinária, FMVZ-Unesp, Distrito de Rubião Júnior s/n, Botucatu, SP.
}

tas e, que não houve $(p>0,05)$ influência do tempo de centrifugação em relação a essa variável. A influência do tempo foi observada apenas no número de leucócitos em protocolos com menor força de centrifugação relativa (FCR). Os quatro melhores protocolos, que obtiveram as maiores concentrações de plaquetas, foram submetidos à análise pelo teste de ELISA para dosar a quantidade de TGF- $\beta$ que não revelou diferença $(p>0,05)$ entre os protocolos.

TERMOS DE INDEXAÇÃO: Cavalo, plasma rico em plaquetas, centrifugação, sangue total.

\section{INTRODUÇÃO}

O Plasma Rico em Plaquetas (PRP) é um hemoderivado utilizado terapeuticamente de fácil obtenção, com boa relação custo/benefício para se obter altas concentrações de fatores de crescimento, melhorando a reparação e regeneração de tecidos (Nikolidakis \& Janses 2008). Adicionalmente tem sido bastante estudado na medicina equina, sendo empregado principalmente em enfermidades como tendinite 
(Maia et al. 2009), desmite, osteoartrite (Carmona et al. 2009) e cicatrização de feridas (De Rossi et al. 2009), entretanto ainda não foi estabelecido um protocolo padrão para a sua obtenção através da centrifugação do sangue total.

As plaquetas armazenam grande quantidade de fatores de crescimento, que são peptídeos sinalizadores responsáveis pela regulação do metabolismo celular. Esta regulação ocorre pelas vias de sinalização intracelular através da interação com um organizado complexo de receptores de superfície celular. Isto resultará no aumento da transcrição dos fatores e produção de proteínas que desencadeiam a proliferação e diferenciação celular, além do aumento da produção da matriz extracelular (Dahlgren et al. 2001) e estimulam ainda a angiogênese facilitando o processo de reparação tecidual (Bosch et al. 2010).

Inicialmente o PRP era obtido através de máquinas de plasmaférese e utilizava-se a trombina bovina para sua ativação. Porém, o interesse em facilitar sua obtenção e diminuir os custos fez com que surgissem equipamentos automatizados e diversos protocolos, inclusive com substituição da trombina bovina por trombina autóloga (Kevy \& Jacobson 2004). As máquinas automatizadas com seus "kits" tornam simples a obtenção do PRP, porém os custos ainda são elevados. Assim, alguns protocolos foram criados para se obter pequenas quantidades de PRP, utilizando-se centrífugas comuns e reduzindo consideravelmente os custos na preparação do hemoderivado (Efeoglu et al. 2004).

Nos protocolos para obtenção do PRP a primeira centrifugação separa as células vermelhas $(7 \mu \mathrm{m}$ de diâmetro) e brancas $(7-15 \mu \mathrm{m}$ de diâmetro) das plaquetas $(2 \mu \mathrm{m}$ de diâmetro), devido à diferença de densidade. Na segunda centrifugação ocorre a concentração das plaquetas, produzindo o PRP e o plasma pobre em plaquetas (PPP) (Foster et al. 2009). Existem diversos protocolos descritos de obtenção do PRP na espécie equina, embora sejam raros os estudos comparando a eficiência desses protocolos.

Schnabel et al. (2007) utilizaram um aparelho específico para a preparação de PRP em equinos, o SmartPReP 2 system $^{4}$. Nesta metodologia era necessária a coleta de 60 $\mathrm{mL}$ de sangue periférico para a obtenção de $20 \mathrm{~mL}$ de PRP, sendo a quantidade de plaquetas 3,77 vezes maior que a do sangue total e a concentração de células mononucleares 1,85 vezes menor no PRP em relação ao sangue total. Esta redução tem grande importância clínica, pois os leucócitos produzem citocinas inflamatórias, tendo efeitos catabólicos in vivo.

Ao considerar o potencial terapêutico do PRP em diversas enfermidades na espécie equina, o custo de aparelhos específicos para sua obtenção e a possibilidade de se obter PRP com custos menores, utilizando-se uma centrífuga convencional, fez com que surgissem alguns protocolos que, embora sejam mais trabalhosos e necessitem de aprendizagem por parte de quem realizará o procedimento, permitem preparo do PRP de forma mais factível (Vendramin et al. 2006).

0 objetivo do presente estudo foi estabelecer um protocolo, entre diversos protocolos disponíveis na literatura

\footnotetext{
${ }^{4}$ Harvest Technologies, Plymouth, MA.
}

para obtenção do PRP, que resulte na maior concentração de plaquetas em relação ao número destas no sangue total e, posteriormente, observar a influência da força de centrifugação relativa e do tempo de centrifugação dos mesmos. Adicionalmente, se avaliou o número de leucócitos presentes no PRP, uma vez que a presença deste tipo celular é indesejável no PRP devido à liberação de citocinas pró-inflamatórias. Além disso, foi realizada a dosagem do TGF- $\beta$ de quatro protocolos que obtiveram as maiores concentrações plaquetárias.

\section{MATERIAL E MÉTODOS}

Foram utilizados cinco equinos hígidos, mestiços, de ambos os sexos e com média de idade de $8,7 \pm 5$ anos, selecionados mediante exame clínico e hematológico prévio, conforme demonstrado no Quadro 1.

Para o teste de cada um dos 10 protocolos previamente estabelecidos, conforme demonstrado no Quadro 2, após prévia preparação asséptica da veia jugular externa, foram colhidos $27 \mathrm{~mL}$ de sangue total de cada animal, utilizando tubos com anticoagulante citrato de sódio a 3,2\% ${ }^{5}$. Após a homogeneização dos tubos, o sangue foi submetido à contagem do número de plaquetas, eritrograma e leucograma em um aparelho de contagem automáti$\mathrm{ca}^{6}$.

Quadro 1. Valores do número de eritrócitos, leucócitos e plaquetas obtidos previamente ao início do experimento

\begin{tabular}{cccc}
\hline Animal & Eritrócitos $\left(\mathrm{x} 10^{6} / \mu \mathrm{L}\right)$ & Leucócitos $(/ \mu \mathrm{L})$ & Plaquetas $(/ \mu \mathrm{L})$ \\
\hline 1 & 6,7 & 6500 & 142000 \\
2 & 8,5 & 9500 & 152000 \\
3 & 7,3 & 7400 & 125000 \\
4 & 8,1 & 8700 & 169000 \\
5 & 7,9 & 9400 & 195000 \\
Média & $7,7 \pm 0,71$ & $8300 \pm 1310$ & $156600 \pm 26745$
\end{tabular}

Quadro 2. Diferentes protocolos de centrifugação (Centr) com variação da força centrífuga relativa (g) e variação do tempo expresso em minutos (min.) provenientes do sangue total de cinco eqüinos hígidos para obtenção do Plasma Rico em Plaquetas (PRP)

\begin{tabular}{|c|c|c|c|c|c|c|c|c|c|c|c|}
\hline \multicolumn{2}{|c|}{ Protocolos } & \multirow{2}{*}{$\frac{1}{120}$} & \multirow{2}{*}{$\frac{2}{120}$} & \multirow{2}{*}{$\begin{array}{c}3 \\
90\end{array}$} & \multirow{2}{*}{$\begin{array}{c}4 \\
90\end{array}$} & \multirow{2}{*}{$\frac{5}{120}$} & \multirow{2}{*}{$\frac{6}{120}$} & \multirow{2}{*}{$\frac{7}{300}$} & \multirow{2}{*}{$\frac{8}{300}$} & \multirow{2}{*}{$\frac{9}{350}$} & \multirow{2}{*}{$\begin{array}{c}10 \\
350\end{array}$} \\
\hline $1^{\circ}$ & Força (g) & & & & & & & & & & \\
\hline Centr. & $\begin{array}{l}\text { Tempo } \\
\text { (min.) }\end{array}$ & 5 & 10 & 5 & 10 & 5 & 10 & 5 & 10 & 5 & 10 \\
\hline $2^{\underline{o}}$ & Força (g) & 240 & 240 & 180 & 180 & 473 & 473 & 640 & 640 & 510 & 510 \\
\hline Centr. & $\begin{array}{l}\text { Tempo } \\
\text { (min.) }\end{array}$ & 5 & 10 & 5 & 10 & 5 & 10 & 5 & 10 & 5 & 10 \\
\hline \multicolumn{2}{|c|}{ Autores } & \multicolumn{2}{|c|}{$\begin{array}{c}\text { Carmona et } \\
\text { al. } 2007\end{array}$} & \multicolumn{2}{|c|}{ Proposto } & \multicolumn{2}{|c|}{$\begin{array}{c}\text { Maia et al. } \\
2009\end{array}$} & \multicolumn{2}{|c|}{$\begin{array}{l}\text { De Rossi et } \\
\text { al.2009 }\end{array}$} & \multicolumn{2}{|c|}{$\begin{array}{c}\text { Del Bue et } \\
\text { al. } 2007\end{array}$} \\
\hline
\end{tabular}

O sangue foi centrifugado com diferentes forças de centrifugação relativa (FCR) e em diferentes tempos de centrifugação conforme cada protocolo, após descansar sob abrigo da luz por cinco minutos. Ao fim da primeira centrifugação foram descartados o botão leucocitário e as hemácias sedimentadas e, após cinco minutos de descanso ao abrigo da luz, o plasma remanescente foi novamente centrifugado conforme a FCR e o tempo do protocolo selecionado. Após a segunda centrifugação descartou-se $50 \%$ do plasma da porção superior, ou seja, plasma pobre em plaquetas (PPP). 0 plasma remanescente, PRP, teve o número de plaquetas e

\footnotetext{
${ }^{5}$ R \& D Systems (Quantikine $囚$, Human TGF- $\beta 1$ Immunoassay).

${ }^{6}$ Ebram, Hemascreen Ebram 18.
} 
de leucócitos quantificados por contagem manual, depois de permanecer em repouso por 30 minutos, na ausência de luz. A quantificação foi realizada em câmara hematimétrica de Neubauer utilizando o líquido de Brecher (Oxalato de amônio a 1\%) como diluente para a contagem de plaquetas e o líquido de Türk para a contagem de leucócitos (Thrall 2007). Adicionalmente, avaliou-se qual o protocolo de obtenção de PRP que, além de apresentar a maior concentração de plaquetas, adicionalmente apresentou a menor quantidade possível de leucócitos.

Foi definido como melhor protocolo o que obteve maior concentração de plaquetas após as centrifugações e a menor quantidade possível de leucócitos, a fim de evitar seus efeitos catabólicos in vivo em uma possível aplicação clínica futura. Adicionalmente, nos quatro melhores protocolos de centrifugação, se levando em consideração a concentração plaquetária, foi realizada a quantificação do fator de crescimento TGF- $\beta$, utilizando-se kit de ELISA humano ${ }^{5}$.

Para a análise dos dados foi utilizado o teste de Friedman, com $5 \%$ de probabilidade, para investigar o efeito do tempo de centrifugação, a força de centrifugação relativa e interação entre eles, considerando como variável resposta a concentração plaquetária, número de leucócitos e quantidade de TGF- $\beta$ obtida. A análise foi conduzida utilizando o pacote estatístico $\mathrm{R}$.

\section{RESULTADOS}

$\mathrm{Na}$ avaliação dos protocolos testados observou-se um aumento de 1,30 a 2,36 vezes em relação à concentração inicial das plaquetas no sangue total, conforme demonstrado no Quadro 3.

Os resultados revelaram diferença $(\mathrm{p}<0,05)$ em relação às concentrações de plaquetas nos protocolos testados, porém os protocolos que apresentaram os melhores resultados (1, 2, 3 e 4) não diferiram ( $p>0,05$ ) entre si (Fig.1).

Com relação ao tempo de centrifugação não foi observado influência $(p>0,05)$ na concentração de plaquetas. Já em relação à concentração de leucócitos observou-se diminuição $(\mathrm{p}<0,05)$ na sua quantidade com o aumento do tempo nos protocolos de 1 a 6 (Fig.2).

A quantidade média de TGF- $\beta$ obtida nos protocolos testados variou de 453,105 a 839,232 pg/mL, não havendo diferença $(p>0,05)$ (Quadro 3).

\section{DISCUSSÃO}

Os benefícios do uso do PRP na reparação de tecidos são de grande interesse da comunidade veterinária, entretanto

\section{Quadro 3. Média e desvio padrão do número de leucócitos, plaquetas e aumento da concentração plaquetária em relação ao sangue total, concentração do TGF- $\beta$, obtida nos diferentes protocolos estudados}

\begin{tabular}{ccccc}
\hline Protocolo & $\begin{array}{c}\text { Leucócitos } \\
\left(\mu \mathrm{L}^{-1}\right)\end{array}$ & Plaquetas $\left(\mu \mathrm{L}^{-1}\right)$ & Concentração & TGF- $\beta(\mathrm{pg} / \mathrm{mL})$ \\
\hline 1 & $4896 \pm 2616^{\mathrm{a}}$ & $343905 \pm 88364^{\mathrm{a}}$ & $2,18 \pm 0.23^{\mathrm{a}}$ & $453,10 \pm 43,18^{\mathrm{a}}$ \\
2 & $2460 \pm 763^{\mathrm{b}}$ & $363600 \pm 31889^{\mathrm{a}}$ & $2,36 \pm 0,34^{\mathrm{a}}$ & $506,23 \pm 198,57^{\mathrm{a}}$ \\
3 & $12960 \pm 1812^{\mathrm{c}}$ & $319160 \pm 76203^{\mathrm{a}}$ & $2,04 \pm 0,35^{\mathrm{a}}$ & $839,23 \pm 206,91^{\mathrm{a}}$ \\
4 & $4146 \pm 1011^{\mathrm{d}}$ & $344915 \pm 28662^{\mathrm{a}}$ & $2,25 \pm 0,49^{\mathrm{a}}$ & $541,15 \pm 143.97^{\mathrm{a}}$ \\
5 & $2497 \pm 1995^{\mathrm{e}}$ & $269165 \pm 35517^{\mathrm{b}}$ & $1,72 \pm 0,49^{\mathrm{b}}$ & \\
6 & $958 \pm 1140^{\mathrm{f}}$ & $209575 \pm 26446^{\mathrm{b}}$ & $1,32 \pm 0,17^{\mathrm{b}}$ & \\
7 & $1080 \pm 1262^{\mathrm{e}}$ & $270680 \pm 42284^{\mathrm{b}}$ & $1,69 \pm 0,30^{\mathrm{b}}$ & \\
8 & $395 \pm 570^{\mathrm{e}}$ & $193415 \pm 29442^{\mathrm{b}}$ & $1,30 \pm 0,64^{\mathrm{b}}$ & \\
9 & $2295 \pm 2580^{\mathrm{e}}$ & $282800 \pm 36108^{\mathrm{b}}$ & $1,85 \pm 0,39^{\mathrm{b}}$ & \\
10 & $451 \pm 346^{\mathrm{e}}$ & $285830 \pm 96073^{\mathrm{b}}$ & $1,79 \pm 0,30^{\mathrm{b}}$ & \\
Média & $3214 \pm 3739$ & $288305 \pm 56601$ & $1,85 \pm 0,36$ & $584,93 \pm 173,36$
\end{tabular}

*Para cada parâmetro, valores seguidos de letras iguais na coluna não diferem entre si $(p<0,05)$. devido a disponibilidade de diversos protocolos para sua obtenção fica difícil a decisão de qual metodologia utilizar. As informações obtidas neste trabalho auxiliam na escolha da melhor técnica de centrifugação para obtenção do PRP para o uso na medicina equina, justificada pelos resultados contrastantes do efeito biológico do PRP na reparação tecidual em função da ausência de protocolos padronizados (Anitua et al. 2006). Tais estudos descrevem diversas velocidades de centrifugação, locais de colheita de sangue,

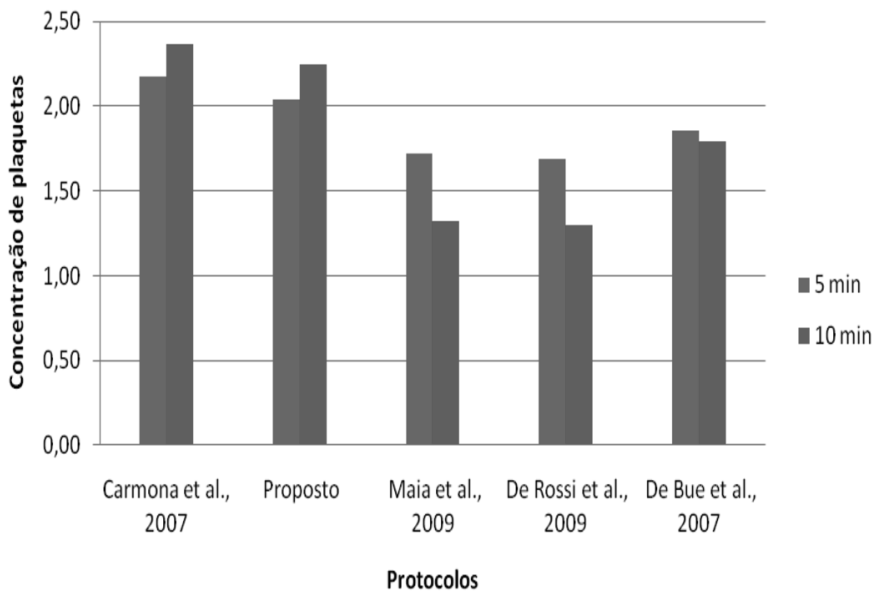

Fig.1. A concentração plaquetária média obtida nos diferentes protocolos de centrifugação.

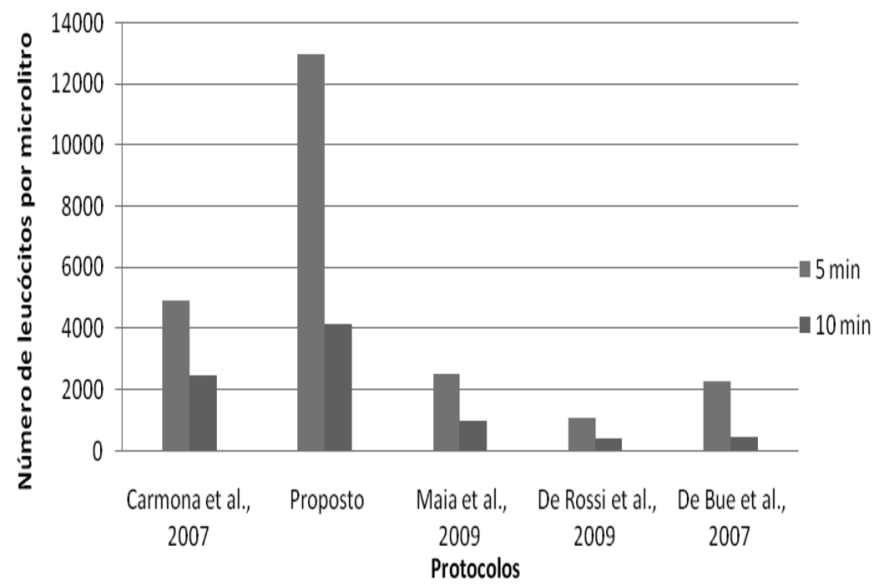

Fig.2. 0 número médio de leucócitos obtido nos diferentes protocolos de centrifugação.

volumes de sangue necessários, proporções do plasma considerados como PRP e substâncias para gelificar o PRP (Aghaloo et al. 2002, Butterfield et al. 2005), o que propicia grande variação na concentração das plaquetas, podendo influenciar nos diferentes efeitos biológicos in vivo (Anitua et al. 2006).

Dentro os diversos tipos de anticoagulantes o citrato de sódio foi o escolhido por preservar a integridade da membrana das plaquetas, sendo o mais adequado no preparo do PRP (Marx 2000a, Trindade-Suedam et al. 2007). Além disso, é possível reverter o efeito anticoagulante com a adição de cálcio a amostra, viabilizando o seu uso em transfusões sanguíneas e de plasma, além das demais aplicações clínicas, como os géis de PRP (Kerr 2003). 
Segundo Nagata et al. (2010) os protocolos com dupla centrifugação obtiveram maiores concentrações plaquetárias do que com uma única centrifugação, o que também foi observado por Arora et al. (2009), fato que justifica a utilização de protocolos com duas centrifugações no presente trabalho.

Para quantificar as plaquetas foi escolhida a contagem manual, pois este método conta as plaquetas individualmente. Os aparelhos automáticos podem identificar agregados de plaquetas como uma única plaqueta, o que pode subestimar os valores (Marx 2000b), levando a resultados não fidedignos, principalmente em casos de trombocitopenia (Nagata et al. 2010). Este fato também foi observado em estudo piloto do presente experimento, com uma grande diferença entre a contagem manual e a automática.

Observou-se que protocolos com FCR altas não obtém altas concentrações plaquetárias, provavelmente por ativar ou lesar as plaquetas durante a centrifugação levando a formação de pellets no fundo do tubo. Maia et al. (2009) contradizem os resultados obtidos ao observarem maiores concentrações com maiores força $g$. Marx (2000a), Gonshor (2002) e Dugrillon et al. (2002) relatam que forças de centrifugação baixas preservam a integridade plaquetária enquanto forças altas ativam prematuramente as plaquetas, o que pode ter ocorrido no presente estudo. Ferraz et al. (2007) testaram diferentes FCR, utilizando sangue de cães, observando que com forças $g$ altas as plaquetas são danificadas, apresentando morfologia alterada, corroborando com os dados obtidos. As maiores FCR ocasionaram maior deposição de leucócitos no fundo do tubo, formando um pellet que não se desfazia facilmente, diminuindo a quantidade de leucócitos presente no PRP. Já nos protocolos com menor força este fato não ocorreu uma vez que os leucócitos e plaquetas contidos no fundo se soltam mais facilmente.

Embora o tempo de centrifugação não tenha influenciado a concentração de plaquetas no presente estudo, Rutkowski et al. (2008) obtiveram melhores concentrações com 10 minutos de centrifugação. Nos protocolos com menor força de centrifugação (1 e 2; 3 e 4; e 5 e 6) a diferença no número de leucócitos ocorreu provavelmente por haver uma menor deposição de leucócitos no fundo do tubo. Isto não ocorreu nos protocolos com maior força $(7$ e 8 e 9 e 10) provavelmente pela maior organização do pellet, o que indisponibilizaria os leucócitos.

A mensuração da concentração do TGF- $\beta$ pode ser realizada uma vez que foi encontrada alta homologia para todos os peptídeos da família deste fator entre os mamíferos (Javelaud \& Mauviel 2004). Segundo McCarrel \& Fortier (2009) não é necessária a ativação plaquetária para a liberação dos fatores de crescimento, por este motivo esta não foi realizada antes da dosagem de TGF- $\beta$. Entretanto a quantidade de TGF- $\beta$ obtida no presente estudo foi inferior ao encontrado por Carmona et al. (2007), fato que pode ser explicado pela não realização da ativação plaquetária, que resulta na liberação dos alpha grânulos, nos quais estão presentes os fatores de crescimento, dado este que contradiz McCarrel \& Fortier (2009).

É consenso que, segundo Marx et al. (1998), o PRP ideal deve conter entre três e cinco vezes mais plaquetas que os níveis fisiológicos, porém no presente estudo não foi possível obter esta concentração utilizando-se a centrífuga. Apesar disso, a utilização da centrifuga vem ganhando credibilidade por ser um procedimento de fácil realização e com baixo custo em relação às demais técnicas (Carmona et al. 2009).

\section{CONCLUSÕES}

Baseado nos resultados obtidos em relação à maior concentração plaquetária nas condições experimentais, o melhor protocolo foi o proposto por Carmona et al. (2007).

Levando-se em consideração a menor concentração leucocitária nos diferentes tempos testados para tal metodologia, o tempo de centrifugação de 10 minutos foi o mais adequado para a aplicação in vivo na Medicina Equina.

Não houve diferença significativa na quantidade de TGF- $\beta$ entre os diferentes tempos testados para os quatro protocolos selecionados, sendo este dado desconsiderado como critério de escolha e ainda diferencial entre as diferentes metodologias.

Agradecimentos.- À Fundação de Amparo a Pesquisa do Estado de São Paulo (FAPESP) pelo o auxilio financeiro e a concessão da bolsa de iniciação cientifica a discente Vendruscolo (Proc.2010/07702-2).

\section{REFERÊNCIAS}

Aghaloo T.L., Moy P.K. \& Freymiller E.G. 2002. Investigation of platelet-rich plasma in rabbit cranial defects: A pilot study. J. Oral Maxillofac. Surg. 60:1176-1181.

Anitua E., Sanchez M., Nurden A.T., Orive G. \& Andia I. 2006. New insights into an novel applications for platelet-rich fibrin therapies. Trends Biotechnol. 24:227-234.

Arora N.S., Ramanauake T., Ren Y.F. \& Romanos G.E. 2009. Platelet-rich plasma: a literature review. Implant Dent. 18(4):303-310.

Bosch G., Moleman M., Barneveld A., Van Weeren P.R. \& Van Schie H.T.M. 2010. The effect of platelet-rich plasma on the neovascularization of surgically created equine superficial digital flexor tendon lesions. Scand. J. Med. Sci. Spor. doi:10.1111/j.1600-0838.2009.01070.x

Butterfield K.J., Bennett J., Gronowicz G. \& Adams D. 2005. Effect of platelet-rich plasma with autogenous bone graft for maxillary sinus augmentation in a rabbit model. J. Oral Maxillofac. Surg. 63:370-376.

Carmona J.U., López C. \& Prades M. 2009. Uso de concentrados autólogos de plaquetas obtenidos mediante el método del tubo como tratamiento de artropatías en caballos. Arch. Med. Vet. 41:175-179.

Carmona J.U., Argüelles D., Climent F. \& Prades M. 2007. Autologous platelet concentrates as a treatment of horses wiith osteoarthritis: a preliminary pilot clinical study. J. Equine Vet. Sci. 27(4):167-170.

Dahlgren L.A., Nixon A.J. \& Brower-Toland B.D. 2001. Effect of betaaminopropionitrile on equine tendon metabolism in vitro and on effects of insulin-like growth factor-I on matrix production by equine tenocytes. Am. J. Vet. Res. 62(10):1557-1562.

De Rossi R., Coelho A.C.A.O., Mello G.S., Frazílio F.O., Leal C.R.B., Facco G.G. \& Brum K.B. 2009. Effects of platelet-rich plasma gel on skin healing in surgical wound in horses. Acta Cirur. Bras. 24:276-281.

Del Bue M., Riccò S., Conti V., Merli E., Ramoni R. \& Grolli S. 2007. Platelet lysate promotes in vitro proliferation of equine mesenchymal stem cells and tenocytes. Vet. Res. Comm. Suppl.1: 289-292.

Dugrillon A., Eichler H., Kern S. \& Klüter H. 2002. Autologous concentrated platelet-rich plasma (cPRP) for local application in bone regeneration. Int. J. Oral Maxillofac. Surg. 31:615-619.

Efeoglu C., Akcay Y.D. \& Erturk S. 2004. A modified method for preparing platelet-rich plasma: an experimental study. J. Oral Maxillofac. Surg. 62(11):1403-1407. 
Ferraz V.C.M., Ferrigno C.R.A. \& Schmaedecke A. 2007. Platelet concentration of plateletrich plasma from dogs, obtained through three centrifugations speeds. Braz. J. Vet. Res. Anim. Sci. 44(6):435-440.

Foster T.E., Puskas B.L., Mandelbaum B.R., Gerhardt M.B. \& Rodeo S.A. 2009. Platelet-rich plasma: From basic science to clinical applications. Am. J. Sport Med. 37(11):2259-2272.

Gonshor A. 2002. Technique for producing platelet-rich plasma e platelet concentrate: Background and process. Int. J. Periodont. Rest. 22(6):547557.

Javelaud D. \& Mauviel A. 2004. Mammalian transforming growth factorbetas: Smad signaling and physio-pathological roles. Int. J. Biochem. Cell B 36:1161-1165.

Kerr M.G. 2003. Plaquetas (trombócitos) e fatores de coagulação, p.45-59. In: Ibid. (Ed.), Exames Laboratoriais em Medicina Veterinária: Bioquímica Clínica e Hematologia. Roca, São Paulo.

Kevy S.V. \& Jacobson M.S. 2004. Comparison of methods for point of care preparation of autologous platelet gel. J. Extracorp. Tech. 36(1):28-35.

Maia L., Souza M.V., Júnior J.I.R., Oliveira A.C., Alves G.E.S., Benjamin L.A. \& Moreira J.C.L. 2009. Platelet-Rich plasma in the treatment of induced tendinopathy in horses: Histologic Evaluation. J. Equine Vet. Sci. 29(8):618-626.

Marx R.E. 2000a. Quantification of growth factor levels using simplified method of platelet-rich plasma gel preparation. J. Oral Maxillofac. Surg. 58:300-301.

Marx R.E. 2000b. Platelet concentrate: a strategy for accelerating and improving bone regeneration. In: Davies J.E. (Ed.), Bone Engineering. University of Toronto, Toronto, p.447-453.

Marx R.E., Carlson E.R., Eichstaedt R.M., Schimmele S.R., Strauss J.E. \& Georgeff K.R. 1998. Platelet-rich plasma: growth factor enhancement for bone grafts. Oral Surg. Oral Med. Oral Pathol. 85(6):638-646.
McCarrel T \& Fortier L. 2009. Temporal growth factor release from platelet-rich plasma, trehalose lyophilized platelets, and bone marrow aspirate and their effect on tendon and ligament gene expression. J. Orthop. Res. 27(8):1033-1042.

Nagata M.J.H., Messora M.R., Furlaneto F.A.C., Fucini S.E., Bosco A.F., Garcia V.G., Deliberador T.M. \& Melo L.G.N. 2010. Effectiveness of two methods for preparation of autologous platelet-rich plasma: an experimental study in rabbits. Eur. J. Dent. 4:395-402.

Nikolidakis D. \& Janses J.A. 2008. The biology of platelet-rich plasma and it application in oral surgery: literature review. Tissue Eng. B, Rev. 14(3):249-258.

Rutkowski J.L., Thomas J.M., Bering C.L., Speicher J.L., Radio N.M., Smith D.M. \& Johnson D.A. 2008. An analysis of a rapid, simple, an inexpensive technique used to obtain platelet-rich plasma for use in clinical practice. J. Oral Implant. 34(1):25-33.

Schnabel L.V., Mohammed H.O., Miller B.J., McDermott W.C., Jacobson M.S., Santangelo K.S. \& Fortier L.A. 2007. Platelet Rich Plasma (PRP) enhances anabolic gene expression patterns in flexor digitorum superficialis tendons. J. Orthop. Res. 25(2):230-240.

Thrall M.A. 2007. Diagnóstico dos distúrbios hemorrágicos, p.170-187. In: Ibid. (Ed.), Hematologia e Bioquímica Clínica Veterinária. Roca, São Paulo.

Trindade-Suedam I.K., Leite F.R.M., Morais J.A.N.D., Leite E.R.M., Marcantonio E. \& Leite A.A. 2007. Avoiding leukocyte contamination and early platelet activation in platelet-rich plasma. J. Oral Implant. 33:334-339.

Vendramin F.S., Franco D., Nogueira C.M., Pereira M.S. \& Franco T.R. 2006. Plasma rico em plaquetas e fatores de crescimento: técnica de preparo e utilização em cirurgia plástica. Revta Col. Bras. Cirur. 33:24-28. 